\title{
Human Resource Information System (HRIS): An Important Element of Modern Organization
}

\author{
Manna Akter Lina
}

Assistant Professor, Department of Business Administration, Dhaka City College, Dhaka, BANGLADESH

Corresponding Contact:

Email: mannaakter.lina@yahoo.com

Manuscript Received: 24 May 2019 - Revised: 12 August 2019 - Accepted: 24 August 2019

\begin{abstract}
Human resources are the most important factor for any organization working in the $21^{\text {st }}$ century. With the increasing effect of globalization and technology, organizations have started to use information systems in various functions of human resources. Human resource information system (HRIS) is not a new concept. Its application is improving day by day with changing the environment. It is one kind of software for data entry, data tracking, and other information about Human Resources like payroll, management, and accounting functions within an organization. An HRIS generally provide the ability to make the plan more effectively, control and manage HR costs; attain better efficiency and excellence in HR decision making; and improve employee and managerial productivity and effectiveness. Lastly, I can say that HRIS has various benefits, but the primary benefit is HRIS stores plenty of data about the employees of the organizations. It also helps in the strategic activities of HR managers and more in training and development, applicant tracking in recruitment and selection and human resource planning, etc.
\end{abstract}

Key Words: Human Resource, Human Resource Information system, Payroll, Talent Management, Recruitment, Training

\section{INTRODUCTION}

Human Resource Management is the organizational function that deals with the issues related to the human who is working in the organization such as remuneration, hiring, performance management, organization development, safety, welfare benefits, employee motivation, communication, training, administration, etc. It is used to the philosophy, policies, procedures, and practices related to the management of people within an organization (French, 1997). This enhances the overall decision-making process; it provides the avenue in which the institutional activities are monitored, executed, controlled, and information is distributed to management, supervisions, employees, etc.

For dissemination of knowledge, an organization can use information systems. MIS is a logical way of providing management with accurate and needful information required for decision making (Okoroma, 2014). The information systems is an essential factor of the human resource management that collect, process, store, and dispense information to make decisions 
in the organizations. Management information systems is a procedure that is used to achieve the desired outcome and distribute information to support decision making and control the organization. It includes planning, organizing, controlling software to store and recover in an accessible form. Wagner (2006) added that MIS is specifically designed to provide information that facilitates the organization to compare actual reference with forecasted and past results. Adams, (2002) reported that MIS is focused on, daily, weekly, and monthly summaries of transactions, which are useful in monitoring and controlling of management activities.

Over the last decade, a large number of organizations gathering, storing and evaluating information regarding their human resources through the use of Human Resource Information Systems (HRIS) software (Ball, 2001; Barron, Chhabra, Hanscome, \& Henson, 2004; Hussain, Wallace, \& Cornelius, 2007; Ngai \& Wat, 2006). In this digital era of information, communication \& technology, most of the human resource functions have rapidly been changing by involving information technologies, (Hendrickson, 2003), (McCrindle, 2006), (Nishad Nawaz Maditheti, 2017), HR has new phase of HR processes and practices such as, e-recruitment, e-performance, elearning, e-selection and other areas to replace the more traditional ones (Gueutal, H.G. and Stone, 2005), (Nishad Nawaz and Anjali, 2012). HRIS can serve as a tool as it shares essential data with the management related to recruitment and retention strategies which can be aligned with the overall corporate. Additionally, by using HR applications, an organization can calculate the costs incurred per employee and its effects on the business as a whole.

\section{Objectives of the Study}

- To know about the human resource information system.

- To understand the need for HRIS in modern organizations

- To know the uses of HRIS in an organization.

- To realize how computerized HRIS is more effective than a manual system.

\section{LITERATURE REVIEW}

HRIS is considered to provide the information required for effective management of the organization, i.e, for decision making relating to human resource. Human resource departments maintain the records of the employees of the organization, including personal history, skills, and salary, etc. The basic level of HRIS is used to help to manage employment relationships within the organization and employees. In the past organizations were used to tracking data on paper and spreadsheets, which was time-consuming to manage record properly. It is one of the factors which contribute to human resource administration functions of an organization. Fully integrated HRIS ought to interface with other systems enabling and enhancing the communication between departments such as payroll system with accountancy system. Pyburn (1983) thinks that HRIS has become important to the successful implementation of corporate strategy. Wade and Tanriverdi (2006) also see it as a strategic organizational resource. In the early development of information systems, it was mainly used for administrative and operational purposes. Forms were used to collect leave requests, workers compensation and accident data, and salary variation and superannuation entitlements. During the 1945 and 1960, only manual work is done to manage all HR activities in the organization, they have human capital issues, employees' morale and formal selection and development method is earlier organization not so much focus on HR-related activities. Then early 1960 to 1970 personnel become change into human resources. In this time HRIS was used mostly for keeping administrative records. The 1970s and 1980s, several factors radically changed towards human resource information systems. After that, from 1980 to current large and small business organization are utilizing HRIS. 
In modern times, HR systems can handle several HR's functions. HR Software is now full of features and self-contained-not just the data storage systems. The developed HRIS will help the organization to store employee data more securely and accurately. At present, HR Professionals can use Modern HRIS systems on a daily-basis for several purposes. By moving to HRIS, organizations can keep more accurate and up-to-date records, allowing them to better prepare for future growth. It has the potential to assist the HR function in developing business strategy and thus enhancing organizational performance (Barney \& Wright, 1998; Broderick \& Boudreau, 1992; Gueutal, 2003; Lawler, Levenson, \& Boudreau, 2004; Lengnick-Hall \& Moritz, 2003).

\section{HRIS PROCESSES}

The current generation of HRIS devolves routine administrative and compliance functions traditionally performed by corporate HR departments and can facilitate the outsourcing of HR (Barron et al., 2004). HRIS also provide HR professionals with opportunities to increase their contributions to the long-term directions of the firm. Usage of information technology has increased the effectiveness and efficiency in planning, recruitment and selection, human resource accounting, training and development, and another process of human resource management (HRM). Similarly, with time, human resource information systems (HRIS) has become an indivisible part of modern organizations (Kapoor, 2012), (Nishad Nawaz and Anjali, 2012). The human resource information system facilitates the human resource department by information processing, increase the communication and reduce the human resource cost (Awazu, Y., \& Desouza, 2003), (Nishad Nawaz, 2012). There are three main functional components in any HRIS: Input, data maintenance, and output (Kovach \& Cathcart, 1999).

- Input: The input function enters personnel information into the HRIS. Data entry in the past had been one way, but today, scanning technology permits scanning and storage of actual image of an original document, including signatures and handwritten notes.

- Data maintenance: The data maintenance function updates and adds new data to the database. Electronic data storage is becoming the standard in large organizations.

- Output: According to Kovach et al., (1999), to generate valuable output for computer users, the HRIS has to process that output, make the necessary calculations, and then format the presentation in a way that could be understood.

\section{ApPLICATIONS OF HRIS IN ORganizations}

Human resource information Systems (HRIS) is a system that helps an organization acquire, store, influence, analyzes, retrieve, and allocate information about an organization's human resources (Tannenbaum, 1990). HRIS is a process that utilizes information technology for the effective management of human resource functions and applications. HRIS can be briefly defined as integrated systems used to gather, store, and analyze information regarding an organization's human resources (Hendrickson 2003). An HRIS can perform several functions from the simple storage and communication of information, to more complex transactions. Actually HRIS is directed towards the HR department itself (Ruel, Bondarouk \& Looise, 2004), but the use of HRIS can provide a number of benefits not only to the HR function, but also line managers, and the organization (Parry, 2009). Some of the applications of HRIS are given below-

Job Analysis and Design Information System: The inputs to the job analysis and design information system include data form supervisors and workers and action guidelines. Inputs also comprise information from external sources to the firm, such as labor unions, competitors, and government agencies. 
Payroll: A variety of payroll systems exist in an HRIS, including some that are fully automated. When looking for an HRIS, be sure that the payroll feature it includes is fully functional and the ability to review payroll information.

Talent Management: Employees are the important resources for any organization. However, the process of talent management, i.e. attracting, recruiting, engaging, developing, and retaining employees is complex. Also, employee turnover cost is very expensive. An HRIS with a special talent management system will help the organization to take better care of their employees.

Time and Labor Management: Time and labor management can be time-consuming. HRIS packages allow employees to input their hours worked and managers to verify vacation requests, and the data is directly fed to payroll. Time and labor management also improves the HR department's ability to track attendance and punctuality.

Skill Inventory: Recording employee skills and monitoring a skill database is yet another use of the HRIS. Such a skill record helps to recognize employees for specific positions or jobs in an organization.

Performance Appraisal: To form a comprehensive overview of an employee, HRIS maintains performance appraisal data. The combination of this information can be used for imparting training and affecting employee mobility in the form of transfer and promotion.

Training Systems: With the extra time an HRIS will give your HR department, they'll likely be able to provide more time and energy into developing training strategies to improve the workforce. An HRIS with a training system will allow the HR department to track and manage all aspects of employee training and is a great feature to have in any HRIS.

Recruiting: HRIS will also permit an HR department more time to focus on their recruitment efforts. Recruitment process is complex, costly, and time-consuming. A good HRIS will provide many different features designed to help the HR department manage each step of the recruitment phase with ease.

HRIS helps an organization to maximize the use of human resources and maintain competitiveness in its market. In most large organizations, human resource information systems (HRIS) provide the technology backbone supporting the complete body of human resource (HR) functions. In this role, HRIS play a significant part in the operation of each component of HR. For these reasons, effective use of HRISs in organizations contributes to overall organizational effectiveness.

\section{BENEFITS OF HRIS IN ORganizATIONS}

An integrated HRIS can be used widely - in administrative, operational, and strategic fields by HR and other managers. It enables the human resource department to make a more active role in organizational planning. Computerization will make forecasting more timely, costeffective, and efficient. With continued technological breakthroughs, HRIS systems are becoming increasingly advanced. One of the most core HRIS functions is intranet HR selfservice. Some larger companies use their intranet today for online appraisals, career management, sentiment surveys, training registrations, and publishing people-related company information. An HRIS supervised by qualified specialists who know technology and HR functional and tactical processes can modernize processes for recruitment and selection, and produce analyses, data, and reports for internal and external use.

With an appropriate HRIS, Human Resources enable employees to do their own benefits updates and address changes, thus freeing HR staff for more strategic functions. Additionally, data essential for employee management, knowledge improvement, career development, and equal treatment is facilitated. There are many benefits that can be enjoyed after implementing an HRIS into an organization, such as: 
- Improved ability to reach candidate regarding new position openings;

- Ability to quickly apply higher selection standards;

- Reduction of paper and related materials and storage;

- Ease in distributing up-to-date materials concerning organizational policies and procedures;

- Improved participation throughout the organization;

- More significant career planning and counseling at all levels;

- Reduction of errors in payroll and employee information database;

- Improved time and attendance tracking abilities and accuracy;

- Quicker information process;

- Greater information exactness;

- Improved planning and program development;

- Enhanced employee communications;

- More transparency in the systems;

- Better ability to take action to environmental changes.

HRIS, which requires resources to design and implement, is believed to create a competitive advantage for organizations through improved accuracy, the provision of timely and quick access to information, the cost savings, quality/customer satisfaction, and innovation (Ngai \& Wat, 2006). HRIS develop business organization's knowledge and, in turn, increases competitive advantage in the marketplace and stakeholder satisfaction. The management uses this strategic data to make a wide range of decisions from work-related decisions regarding an individual employee to large scale decisions about corporate strategy.

\section{CONCLUSION}

Human resources information systems (HRIS) can play a role in a company's HR function. It works as an element of the organization, and a good HRIS will provide vital information about human resources needs and capabilities; this information will assist the management team in establishing the organizational mission and setting goals and objectives. HRIS is not limited to the computer hardware and software applications that comprise the technical part of the system: it also includes the people, policies, procedures, and data required to manage the HR function. It helps the organizations in planning their human resources, both quantitatively and qualitatively. By adding the employee's information in HRIS and analyzing that information using the same assists in reducing various costs. Besides these advantages, HRIS apply strategic activities by HR managers. These activities include training and development management, succession, applicant tracking in recruitment and selection and human resource planning, personnel information and identification, attendance tracking, salary planning, absenteeism analysis, turnover analysis, work schedule, etc. By these ways, the performance of an organization can be increased day by day.

\section{REFERENCES}

Adams, R. J. (2002). Strategic Information System and Libraries Library Management, Vol. 16 issue: 1, pp 11 - 17.

Awazu, Y., \& Desouza, K. C. (2003). Knowledge management. Human Resource Magazine, 48(11), 107.

Ball, K. S. (2001) "The use of human resource information systems: a survey. Personnel Review". 30, 677-693.

Barney, J. B., \& Wright, P. M. (1998). On becoming a strategic partner: The role of human resources in gaining competitive advantage. Human Resource Management, 37(1): 31-46.

Barron, M., Chhabra, D., Hanscome, R., \& Henson, R. (2004). Exclusive Panel Discussion: Tips and Trends in HRIS. HR Focus, 81(5): 6-7.

Broderick, R., \& Boudreau, J. W. (1992). Human resource management, information technology, and the competitive edge. Academy of Management Executive, 6(2): 7-17. 
French W. L. (1997). “Human Resource Management” Third Edition, Houghton Mifflin Company, U.S.A. ISBN No. 0-395-47278-4 pp. 44-63

Gueutal, H. G. (2003). The Brave New World of E-HR. Advances in Human Performance and Cognitive Engineering Research 3: 13-36.

Gueutal, H.G., \& Stone, D. L. (2005). The Brave New World of EHR: Human Resources Management in the Digital Age. Jossey-Bass, San Francisco, CA.

Hendrickson, A. R. 2003. Human Resource Information Systems: Backbone Technology of Contemporary Human Resources. Journal of Labor Research, 24(3): 381-394.

Hussain, Z., Wallace, J., \& Cornelius, N. E. (2007). The use and impact of human resource information systems on human resource management professionals. Information \& Management, 44(1): 74-89.

Kapoor, S. (2012). Human resource information system in New World. Prime Management Journal, 4(2), 123-134.

Kovach, K. A., \&Cathcart, C. E. (1999). Human Resource Information Systems (HRIS): Providing Business with Rapid Data Access, Information Exchange, and Strategic Advantage. Public Personnel Management, 28(2), 275-282.

Lawler, E. E., Levenson, A., \& Boudreau, J. W. (2004). HR Metrics and Analytics: Use and Impact. Human Resource Planning, 27(4): 27-35.

Lengnick-Hall, M. L., \& Moritz, S. (2003). The Impact of e-HR on the Human Resource Management Function. Journal of Labor Research, 24(3): 365-379.

McCrindle, M. (2006). New Generations at Work: Attracting, Recruiting, Retraining \& Training Generation Y. McCrindle Research, Sydney.

Nishad Nawaz. (2012). Time \& cost savings advantages with the usage of a human resource information system in select software companies in Bangalore City. Indian Journal of Applied Research, 1(12), 161-163.

Nishad Nawaz and Anjali. (2012). Automation of the HR functions enhances the professional efficiency of the HR professionals-A Review. International Journal of Management, IT and Engineering, 2(6), 402-416.

Nishad Nawaz Maditheti. (2017). A Comprehensive Literature Review of the Digital HR Research Filed. Information and Knowledge Management, 7(4), 15-20.

Ngai, E.W.T. and Wat F.K.T. (2006) "Human resource information systems: a review and empirical analysis". Human Resource Information Systems. 35(3), 297-314.

Okoroma, N. S. (2014). Perspectives or Educational Management, Planning, and Policy Analysis. Port Harcourt: Minson Publishers.

Parry, E. (2009). The benefits of using technology in human resources management. In T. Coronas \& M. Oliva, Encyclopedia of human resources information systems: Challenges in E-HRM: 110-116.

Pyburn, Philip J. (1983) "Linking the MIS Plan with Corporate Strategy: An Exploratory Study." MIS Quarterly. 1-13.

Ruel, H., Bondarouk, T., \& Looise, J. K. (2004) E-HRM: Innovation or Irritation. An Explorative Empirical Study in Five Large Companies on Web-based HRM. Management Revue, 15(3), 364-381.

Tannenbaum, S. I. (1990). HRIS information: User group implication. Journal of Systems Management, $41,1,27-32,36$.

Tanriverdi, Hüseyin (2006) “Performance Effects of Information Technology Synergies in Multibusiness Firms." MIS Quarterly. 30(1), 57-77.

Wagner, H. T. (2006). How Social Capital among Information Technology and Business Units Drives Operational Alignment is IT Business Value, Journal of Management Information System Vol. 31, issue I.

$--0--$ 